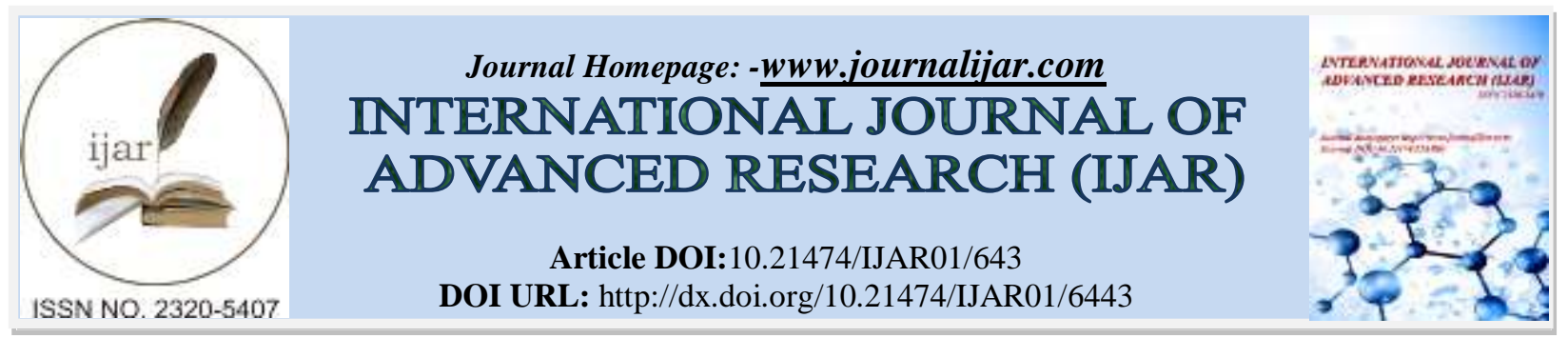

RESEARCH ARTICLE

\title{
BRIDGING THE GAP OF QUALITY EDUCATION PROVISION IN SECONDARY SCHOOLS: A REFECTION ON EXISTING INSTRUCTIONAL SUPERVISORY PRACTICES.
}

\section{Solomon Gitonga Mwaniki ${ }^{1}$, Dr. Felicita W. Njuguna ${ }^{2}$ and Dr. Florence M. Itegi ${ }^{3}$.}

1. Doctorate student in the Department of Educational Management Policy and Curriculum Studies, School of Education, Kenyatta University, P. O. Box, 43844-00100, Nairobi.

2. Department of Educational Management Policy and Curriculum Studies, School of Education, Kenyatta University P. O. Box, 43844-00100, Nairobi.

3. Department of Educational Management Policy and Curriculum Studies, School of Education, Kenyatta University. P. O. Box, 43844-00100, Nairobi.

\section{Manuscript Info}

[.........................

Manuscript History

Received: 04 December 2017

Final Accepted: 06 January 2018

Published: February 2018

\section{Keywords:-}

Instructional Practices, Quality

Assurance and Standards Officers,

School Administrators, Collegial

Leadership.

\section{Abstract}

The impact of instructional supervision in enhancing provision of quality education in learning institutions appears to be in doubt worldwide. The overall objective of the study was to establish the effectiveness of the instructional supervisory practices exercised by instructional supervisors in schools and their contributions towards quality education provision in secondary schools in Nairobi and Machakos counties, Kenya. The study sought to find out how Quality Assurance and Standards Officers prepared for conducting instructional supervision, assess how Quality Assurance and Standards Officers conducted instructional supervision in schools, evaluated and how Quality Assurance and Standards Officers provide preliminary instructional supervision reports and feedback in schools. Findings revealed that although the instructional supervisory practices exercised by QASOs in the schools appear well organized, there are certain inadequacies; the QASOs don't do sufficient preparations before conducting instructional supervision in schools, QASOs hardly engaged principals and heads of departments in pre-observational conference, QASOs spend most of the time checking teachers' professional records, and there was usually no sufficient time for delivering feedback and engaging teachers in the plenary meetings. The study recommends that to reverse the trends, instructional supervisors need to be taken through intensive capacity building training to improve on how they exercise their instructional supervisory practices.

Copy Right, IJAR, 2018,. All rights reserved.

\section{Introduction:-}

In a study conducted by Romano (2014), it emerged that one of the most frequent complaints from teachers in respect to the processes of the pre-observation, observation, and post-observation (feedback) cycle, is that it does not help them improve their quality of teaching. This could be an indicator that there are certain weaknesses in these processes. Richard \& William (1981) found that poor skills related to instructional supervisor's effectiveness in 
conducting conferences in terms of social-emotional and interpersonal communication could lead to the conferences being none productive in teacher instructional improvement and at its worst interfere with future observations productivity because teachers might form negative perceptions towards being observed in the classroom set-up.

In a study conducted in Turkey to explore the external instructional supervisory process from the standpoint of English Language Teachers (Kayaoglu, 2012), it was established that external educational instructional supervisory process did not add any pedagogical or professional value to teachers, mainly because of the manner in which the external instructional supervisory process was conducted in learning institutions. This observation is in tandem with the study findings in another study in Bangladesh schools (Govinda \& Tapan 1999), where it was observed that traditional instructional supervision as a means of improving quality education in schools focused on teachers and their performance with little regards to supporting the teachers. The study recommended that there was need for the teacher instructional supervision to focus on supporting the teachers and adopting a participatory approach in supervision where the supervisor directly gets involved in the classroom teaching.

Daresh and Playko, (1992), concurs with these sentiments in a research conducted in Boston on how "professional instructional supervision" of teachers impacted on curriculum implementation in schools. The study reveals that "professional supervision" done in areas of checking on lesson plans, schemes of work, registers and other administrative documents had positive impact in academic performance of pupils

\section{Literature Review:-}

\section{The Instructional Supervision Practices by QASOs:-}

According to the Handbook for supervision of educational instructions the inspectors (QASOs) are responsible for numerous roles, key among them being;

Advising the Government on the type and quality of education being offered in the country; inspecting all educational institutions regularly and compiling appropriate reports; advising the Government on the trends observed in the learning institutions in the areas of equity, access, equality, gender, curriculum delivery, learning, teaching materials, leadership staffing governance, health care, career guidance, discipline,, curriculum evaluation, pre-service and in-service training of teachers; advising on curriculum evaluation in collaboration with Kenya National Examination Council; and advising the stakeholders on education matters pertaining to curriculum delivery, assessment and the provision of resource. (Republic of Kenya, 2000:7).

From the above roles, it's apparent that the ESQAC have been mandated to carry out supervisory, evaluative and advisory roles, all in furtherance to quality education provision. Thus, if the ESQAC were vibrant through their field officers (QASOs), their impact would be felt in the public secondary schools as far as ensuring education quality development and assurance is concerned. Nonetheless, many are times is when teachers in public schools are wholesomely blamed for low quality education provision, leaving out the QASOs primarily because they don't deal directly with the students. In fact at this era of transparency and accountability, it's unfortunate to note that the public does not know the existence of QASOs or their roles because they are sparingly visible on the ground (Okumbe $1987 \&$ Muchanje 2004).

In a study conducted in Turkey on the necessity and benefits of education supervision, it was established that, teachers and administrators felt that education supervision was essential for "exploring to what extent educational aims are attained and diagnosing educational issues and troubleshooting" Hasan, (2012:151). However, in the same study, it was established that educational supervisors restrictively focused on control, evaluation and these lead to supervised teachers being self-defensive and concealing errors, and ultimately creating communication barriers and poor trust between supervisors and teachers. The study recommended that instructional supervisors needed to be trained first on; instructional leadership, coaching, mentoring and on-the-job training before they could be trusted to act as guides for teachers instructional improvement.

Similarly, in Addis Ababa government secondary schools, Tesfaw and Hofman (2012) found that teachers wished to be supervised by professionals who had knowledge and skills of supervision, and who exhibited collaborative and friendly approaches in instructional supervision exercise. In Kenya, Kimuya (2004:65), revealed that "teachers and supervisors were not working in collaboration to improve teaching in schools..." and that lack of teacher-supervisor collaboration was mainly due to teachers' lack of trust and confidence on instructional supervisors coupled with negative approach to supervision. Thus, this study probed the effectiveness of QASOs on quality education 
provision in the light of their supervisory, evaluative and advisory roles.

Preparation for Conducting Instructional Supervision:-

For the supervision excise to be productive, the QASOs must plan their school visits well in advance. The Handbook for supervision of educational institutions (Ministry of Education, 2000) talks of prior plans, where preparations are made at the levels of QASOs themselves and in the institutions to be visited. Indeed, Tyagi (2011) established that effective instructional supervision in schools needed a thorough review of previous supervision reports as a preparation aspect for supervision.

The QASOs should have an annual costed strategic plan for supervision for the whole county where all the human and financial resources are effectively and efficiently mobilized towards achieving conducting meaningful instructional supervision. As part of preparation, the QASO Panel should aim to arrive at and report to the school they intend to inspect early (7.45 to 8.00) a.m. (ibid) so that they can maximize on what they see, hear and read in the specific school.

At the institution level, the schools should be informed formally on the areas to be inspected by being given two to three months notice to prepare for documents to submit to the panel chairperson, unless the supervision is of an emergency type (ibid). Olembo et al., (1992:148) note that; 'Supervision has, at times been marked by impromptu, irregular visits by inspectors aimed at 'catching' the teacher doing wrong'. Such an approach of conducting supervisory practices has adverse effects on the teachers because they feel mistrusted, unloved and spied on. Further, it's assumed by the supervisors that teachers are the main culprits of lowering the quality of education is teachers. Thembinkosi, T., (2013) found that the majority of teachers wanted to be notified about the classroom visits by supervisors well in advance to prepare for the exercise of supervision.

When institutions are informed in advance that they will be inspected, this provides the school with 'an opportunity to engage itself in a thorough review and puts teachers on their toes to prepare adequately for the inspectors, thus making the pupils benefit even before the supervision takes place' ((Ministry of Education, 2000). This study evaluated the level of preparedness made by the QASOs before they visit schools and specifically the instructions they give to schools so that they can prepare for being visited for instructional supervision.

\section{Conducting Instructional Supervision:-}

In a study of instructional supervision and teacher satisfaction, Fraser (1980:224) found that "the improvement of the teaching learning process was dependent upon teacher attitudes toward supervision". Fraser further noted that unless teachers perceive instructional supervision as a process of promoting professional growth and student learning, the supervisory practice would not bring the desired effect. In this regard, Kutsyuruba, (2003), Sergiovanni \& Starratt, (2007) and Zepeda,(2007) are in consensus that, the attitude and satisfaction of teachers toward instructional supervision depends largely on such as a harmonious teacher-supervisor relationship and availability of supervisory choices based on teachers' needs, as well as mutual trust, respect and collaboration among supervisees and supervisors.

In a study conducted in Botswana to determine how instructionalsupervision was carried out in schools (Moswela, 2010), it was found that the environment in which instructionalsupervision took place in schools was rather hostile and intimidating to teachers to make any meaningful impression on the improvement of teaching standards. Thus, effectiveness of instructional supervisors was impeded by the environment which they had knowingly or unknowingly actively created in schools. The instructional supervision process can be conducted through two broad approaches, that is; scientific and bureaucratic, and the democratic and humane management approach of supervision. The scientific and bureaucratic approaches of supervision are authoritarian in nature because they mainly cultivate an environment of manager-subordinate relationship (Sergiovanni \& Starrat, 2002). In this approach, the teachers are seen as workers to be directed and monitored and the role of supervisor is viewed as that of ensuring that schools comply with the set rules and regulations (Sergiovanni \& Starrat, 2002; Bolin \& Panarities, 1992).

From this perspective, it can be noted that supervisors visit schools to mainly inspect, assess or peruse documents and records such as; lesson plans, lesson notes, record of work, schemes of work, registers, etc so as to ascertain whether effective learning has been taking place. Perusing of documents and records constitute "what you see" and "what you read" and when over-emphasized at the expense of "what you hear" it can be detrimental. Okumbe, 
(1998:25) notes that, 'excess paper work and rigid rules, leads to inefficiency'. Thus, making the supervision process to be centered on whether teachers have unkempt/kept and un-updated/updated records which cannot be considered to be effective supervision process. When this approach of supervision is used, supervisors make irregular and inadequate inspectoral follow-up as a means of ensuring that teachers do the routine tasks and not necessarily to improve the teacher. However, as found by Usman (2015) regular professional instructional supervision using robust supervision strategies like checking of students' notebooks, checking teachers' lesson plan/notes and inspection of teachers' record keeping have significant correlation with teachers' performance and academic achievement of students in Secondary Schools. Similarly, Njiru (2014) established that instructional supervision by supervisors improved the teachers' abilities in the preparation of curriculum documents and ultimately timely coverage of the syllabuses

In the democratic and humane management approach of supervision, the concern for the "human factor" in organization became paramount (Okumbe, 1998). Mary Follett (1868-1933), as quoted by (Knezevich, 1975) emphasizes that this approach advocated for 'greater attention on obtaining cooperation of employees and helping them identify more closely with the organization and its goal.

Thus, through this approach, the supervisor would pay attention to the concerns of the teachers and will exhibit deliberate effort to improve the teachers' ability in handling learners and delivering content (Okumbe, 1998). This approach is also based on the fact that 'teachers would do their best in a supportive environment' (Tracy, 1995:323). One would therefore, assume that supervisors using this approach will inform the schools as to when they will visit them so that they prepare themselves and that when the supervisors visit the schools, the teachers will raise worthwhile issues of quality education provision in critical areas of concern and through discussion, way forward would always emerge.

Maybe, it's through such a premise that the teachers will feel valued and recognized and consequently, a cordial relationship between the teacher and the supervisor can be established right from the time the supervisors arrive in the schools. This study will probe the extent to which the QASOs cultivate an atmosphere of democracy and human understanding so as to guide the interactions between the teacher and the supervisor, so that the teacher feels free to air his or her views and does not become defensive.

Different models of supervision exist from which education supervisors can borrow from in different times. These models include; the developmental model, differentiated model, collaborative model and the clinical model which is the latest (Okumbe, 1998). Supervision models are blue prints of the dynamics of the supervisory transactions between the instructional supervisor and the teacher (Miller \& Moreetsi, 2008) and the transactions vary according to the different instructional supervisors and teachers expectations, relationships and anticipated outcomes (Stoller, 1996). However, it is usually left to the discretion of the instructional supervisor to determine the model(s) of supervision rely on when conducting instructional supervision.

In the developmental model, the teachers are seen as individuals undergoing continuous growth and development in their career (Zepeda, 2007). The growth and development of the individual teacher can be perceived as the increase in experience accumulated over time and strengthening of the teachers' abilities in dealing with learners in varied environments year after year. Based on this model therefore, the role of the supervisor when dealing with teachers would require him to first identify the needs of the teacher so as to effectively assist the teacher towards accelerated growth and development (Glickman et al., 2007). The Task Force on Alignment of the Constitution with Education 2010 established that Quality Assurance Services in Educational Institutions is manifested with uncoordinated decision-making at all levels, hampered by inadequate data and lacks enough sense of urgency on follow-ups (Republic of Kenya, 2011).

In the Kenyan context, one would advise that, before the QASOs visit a school, they need to peruse the teachers files and have a sitting with the respective Teachers, just to be briefed objectively on the professional growth and development status of the teachers. It's from such a background that the interaction between the supervisor and the teacher can be more productive. But because time is always a limitation, the supervisors are advised to 'observe teachers teaching or working ... discuss with the teacher his or her ideas about students, teaching, and instructional improvement' (Glickman et al., 2007). 
Through the above avenues, the supervisor is well-placed to advise the teacher even sometimes unaware that she or he is actually offering advisory service. It's also through such engagement that the supervisor will have deeper insights of the weaknesses of the teachers and even strong points of the specific teachers which can be used elsewhere to other teachers.

In the differentiated model, teachers are viewed as professionals who are experts in instruction (Glatthonn, 1998) and the role of the supervisor is that of facilitating teachers to work professionally. In this respect then, QASOs should be proactive in facilitating existence of excellent conducive environments in schools; the officers should be keen in ensuring the Teachers embrace good working environments by promoting participatory and democratic principles of leadership where all teachers and other stakeholders can cooperatively interact and benefit from one another.

Commenting on the collaborative model of supervision in schools, Harris and Ovando, (1992:13), observe that, collaborative supervision is whereby; 'people with diverse expertise work jointly'. In a collaborative system, all stakeholders in education in a school set up work jointly, sharing experiences in different forums and consequently improving the productivity of one another collectively. The role of the supervisor in the collaborative supervision model would be that of encouraging and motivating all the stakeholders towards moving to higher heights of teamspirit whose focus is to make teaching-learning process more effective. In this study, attempts will be made to probe how efficiently the QASOs have been able to influence all stakeholders in public secondary schools towards working as a team so as to uplift the standards of education.

According to Goldhammer (1980), Clinical supervision as practiced in the education sector can be defined as 'That phase of instructional supervision which draws its data from first hand observation of actual teaching events, and involves face to face interaction between the supervisor and the teacher in the analysis of the teaching behaviors and activities for instructional improvement'

Clinical supervision yields data from the events that take place in classroom and the data are analyzed to form the basis of designing programmes, procedures and strategies of improving the student's learning via improving the teacher (Okumbe, 1998; Cogen, 1973). To illustrate the importance of the events that take place in the classroom, the Handbook for supervision of educational institutions (Ministry of Education, 2000:34), contends that 'what happens in the classroom, lecture theatre or play area, should be the central concern of any supervision'. In a study by Arsaythamby V, Mary M. A, Rozalina K., (2013) on the influences of clinical supervision on the teaching performance of secondary school teachers of Malaysia found that clinical supervision helped instructional supervisors indentify teachers' classroom shortcomings and consequently, help address them ultimately teachers' ability to facilitate teaching and learning for more effective and enhanced students' understanding

From the foregoing explanation, it's noted that clinical supervision emphasizes on data collection based on "what you see (observation), hear (discussion), and read (documentation)". A basic prerequisite for the process to proceed successfully is for the teachers to have a positive mind-frame towards being observed by the supervisor when the actual teaching is taking place. In fact, Okumbe, (1998:186), compares the application of clinical supervision to the teaching practice undertaken by all the teacher trainees. Like the teaching practice, a positive supervisory relationship grounded by trust, respect, rapport, and empathy. This study will examine how effectively clinical supervision has been conducted in schools as a means of obtaining data to help teachers become better teachers. Maybe, also it's the high time such data are used as a reference during promotions of teachers. An article in the Standard Newspaper of Wednesday $27^{\text {th }}$, October 2010 on education argue that the "Medicine for the failing quality of education in public schools is tying pupil's performance to teacher's promotion".

\section{Delivery of Supervisory Reports to School:-}

Delivery of the feedback occurs during the final meeting between the QASO panel, the principal and the staff. During these meetings, major highlights or findings of the supervision are discussed and 'the discussion should be professional and friendly' (Ministry of Education, 2000:13). Numerous studies have established that productive feedback and follow-up initiatives relative to supervision are lacking in the Kenyan supervision system (Olembo, Wanga, \& Karagu, 1992; Wanga, 1988). As Wanga noted, opportunities for follow-up regarding recommendations based on supervision, such as the need for in-service training of teachers are badly lacking. This is despite research on professional development suggesting that the right kind of approach can increase teacher quality significantly (Dolton and van der Klaauw, 1999). Semiha, Fatma \& Nalan (2011). 
In a study titled "Education Supervisors' Views Regarding Efficiency of System and In-service Training Courses" established that; most (30.76\%) of educational supervisors supported authorization and enforcement of their reports in schools that they had supervisedas a means of improving quality of education offered in their schools. This is justified, because school inspectors are not members of these schools and their attempts to provide follow-up initiatives, for example, in facilitating in-service training programs based on their recommendations, are highly limited.

The problem of the lack of feedback is not unique to Kenya. In a study that examined primary and secondary teachers' and head teachers' perceptions of supervision in 5 local authorities in UK, Dean (1995) reported that lack of feedback to teachers was a major cause of frustration among teachers. Also, teachers in this study agreed that they were disturbed whenever an inspector simply left the lesson without saying anything. However, in Australia a study by Naci (2012) established that, from the view point of English Language Teachers, supervision is not of any pedagogical or professional value because its feedback does not have a positive effect on teachers' performance.

\section{Compiling of Supervision Reports:-}

After the school visits, the QASOs are supposed to compile reports on their findings in the field and dispatch these reports to the schools, S-CEOs, CQASOs, S-CQASOs and in the Planning and development department of the MoEST. The Handbook for Supervision of Educational Instructions', notes that the collection and collation of data by QASOs are mainly done by use of the detailed schedules which are considered objective, reliable, comprehensive, and focused (Ministry of Education, 2000:14).

It's expected that from these schedules, the QASOs can compile appropriate supervision reports bordering on quality education provision that can benefit the specific school and other schools, and further advise the Government on the type and quality of education being offered in the country. From these quality assurance reports, policy guidelines on quality education provision can be drafted and or existing policies on quality education provision can be refined. This study will establish whether the schools inspected by QASOs do promptly receive implementable reports from the QASOs each time there is supervisions and whether the Teachers and teachers perceive these reports as valuable in helping to uplift the quality of education in the schools. On a large scale, this study will establish whether QASOs reports are used in policy and guidelines formulation towards promotion of quality education in the education sector.

\section{Purpose and Objectives of the Study:-}

The purpose of this study was to investigate the instructional supervisory practices exercised by instructional supervisors in schools and their contributions towards quality education provision. The research focused on the following three objectives;

1. To establish how Quality Assurance and Standards Officers prepare for conducting instructional supervision

2. To assess how Quality Assurance and Standards Officers conducting instructional supervision in schools

3. To determine how Quality Assurance and Standards Officers provide preliminary instructional supervision reports and feedback in schools

\section{Research Design and Methodology:-}

This study utilized descriptive survey research design and had a target population of 1481(N) persons comprising of; 21 QASOs, 365 School Principals and 1095 HoDs. From the target population, the study used stratified, purposeful and random sampling techniques, to obtain a sample size of 460 (n) respondents consisting of; 21 QASOs, 110 school principals and 329 HoDs). Data was collected using questionnaires and interview guide. The data was analyzed using the statistical package for social sciences (SPSS).

\section{Research Findings and Discussion:-}

\section{Preparation for Conducting Instructional Supervision:-}

The study sought to establish how the QASOs prepared themselves and the teachers before to engaging in the actual exercise of conducting instructional supervision in schools. To this effect, the study first sought to establish whether QASOs wrote letters to learning institutions notifying them that they will be visiting them as required (Ministry of Education, 2000) and whether QASOs used previous instructional supervision reports and recommendations for the various respective schools as reference documents for preparing to conduct instructional supervision in a given school. The results of these is reported in Table 1.1 
Table 1.1:-Notification to Schools of Instructional Supervision Visits and Utilization of Previous Supervision Reports by QASOs

\begin{tabular}{|c|c|c|c|c|c|c|c|c|c|c|c|c|c|c|c|c|c|c|}
\hline \multirow{3}{*}{$\begin{array}{c}\text { Statement } \\
\text { Variable }\end{array}$} & \multicolumn{6}{|c|}{ School Principal } & \multicolumn{6}{|c|}{ Heads of Department } & \multicolumn{6}{|c|}{ QASOs } \\
\hline & \multicolumn{2}{|c|}{ Yes } & \multicolumn{2}{|c|}{$\begin{array}{c}\text { To some } \\
\text { little extent }\end{array}$} & \multicolumn{2}{|c|}{ No } & \multicolumn{2}{|c|}{ Yes } & \multicolumn{2}{|c|}{$\begin{array}{c}\text { To some } \\
\text { little extent }\end{array}$} & \multicolumn{2}{|c|}{ No } & \multicolumn{2}{|c|}{ Yes } & \multicolumn{2}{|c|}{$\begin{array}{c}\text { To } \\
\text { some } \\
\text { little } \\
\text { extent }\end{array}$} & \multicolumn{2}{|c|}{ No } \\
\hline & $\mathbf{n}$ & $\%$ & $\mathbf{n}$ & $\%$ & $\mathbf{n}$ & $\%$ & $\mathrm{n}$ & $\%$ & $\mathrm{n}$ & $\%$ & $\mathbf{n}$ & $\%$ & $\mathbf{n}$ & $\%$ & $\mathbf{n}$ & $\%$ & $\mathbf{n}$ & $\%$ \\
\hline $\begin{array}{l}\text { QASOs } \\
\text { notify } \\
\text { schools at } \\
\text { least three } \\
\text { weeks } \\
\text { before the } \\
\text { visit. }\end{array}$ & 18 & 16.7 & 18 & 16.7 & 72 & 65.5 & 64 & 22.1 & 107 & 36.9 & 119 & 41 & 2 & 11.8 & - & - & 15 & 88.3 \\
\hline $\begin{array}{l}\text { QASOs use } \\
\text { previous } \\
\text { supervision } \\
\text { report. }\end{array}$ & 35 & 31.8 & 36 & 33.3 & 37 & 34.3 & 102 & 35.1 & 114 & 39.2 & 75 & 25.6 & 5 & 29.4 & - & - & 12 & 70.6 \\
\hline
\end{tabular}

From Table 1.1, it is observed that, majority $72(65.5 \%), 119(41.0 \%)$ and 15(88.3\%) of school principals, heads of departments and QASOs respectively indicated that QASOs hardly wrote letters to schools to notify them at least three weeks in advance that they were due to visit them, only 18(16.7\%) of school principals and $64(22.1 \%)$ of the heads of department indicated that they receive letters informing them that they will be visited by QASOs. This indicates that most schools are hardly notified of impending QASOs' instructional supervision visits and therefore when such visits are actualized, teachers are unaware and ill unprepared for them a situation that may make them underperform.

These findings are consistent with Mwaura (2014) who found that QASOs hardly issued notices to schools to be visited, hence most head teachers and teachers were caught unawares. However, according to the findings of Thembinkosi (2013), majority of teachers wanted to be notified about the school or classroom visits by supervisors well in advance because as Ogandoh (2015) had noted, the effects of not informing the schools to prepare for instructional supervision makes the teachers feel; mistrusted, spied on, threatened and this can reduce the productivity of an instructional supervision exercise because teachers perceive QASOs conducting instructional supervision as being on a fault finding mission.

Indeed, the Handbook for supervision of educational institutions (Ministry of Education, 2000) talks of prior plans, where preparations are made both at the levels of QASOs' themselves and in the institutions to be visited. However, as one County QASO justified or observed;

"...if instructional supervision is for the purpose of establishing what is happening in the school, giving notice to a school will not yield results because what will be observed will be staged managed..."

The documented adverse effects of not formally informing schools of instructional supervision visits by QASOs as provided for is so bad that the justifications given by one of the County QASO should not hold. As noted in the literature review, majority of teachers like to be notified about classroom visits by supervisors well in advance to prepare for the exercise of supervision (Thembinkosi, 2013). Effective instructional supervisors should not only be able to uncover any "stage managed" preparations which does not benefit the instructional process but should also be able to advice accordingly. Indeed, when schools are notified in advance of an impending instructional supervision exercise, part of the preparations in the schools should aim to do "things" right and ultimately improve quality of education.

In respect to utilization of previous instructional supervision reports as an avenue of preparation for conducting instructional supervision, Table 1.1 indicates that many 37(34.3\%) of school principals and $114(39.2 \%)$ of heads of departments felt that previous supervision reports were hardly used and only used to a little extent respectively to inform the preparation for instruction supervision of schools by the QASOs. However, majority 12(70.6\%) of the 
QASOs reported that they hardly used previous instructional supervision reports when preparing to conduct instructional supervision in a given school. This implies that generally there are no optimal utilization schools' previous instructional supervision reports in terms of checking of implementation of QASOs recommendations as a preparation for subsequent instructional supervision exercises in schools. This essentially denies the QASOs the opportunity to verify the extent of implementation of their previous instructional supervision recommendations and appropriately refine how they will conduct their current instructional supervision exercise for optimal instructional benefit of a given school.

These findings are contrary to Tyagi (2011) who established that effective instructional supervision in schools needed a thorough review of previous supervision reports as a preparation aspect. When QASOs make impromptu schools visits for intensive instructional supervision without having perused through previous instructional supervision reports conducted in the respective schools, this is unlikely to show progress or lack of it terms of improving teachers instructional competences. As noted in the literature view, in the European Union countries preparation for conducting schools evaluation starts with a preliminary phase of collecting and analyzing information data on schools by Education Quality Personnel, which allows evaluators to establish the profile of the school to be visited and better focus the evaluation (European Commission/EACEA/Eurydice, 2015). One would therefore advise that for monitoring and effectiveness purposes, previous instructional supervision reports should form base-line reference documents for preparing for instructional supervision. This study established that this was hardly done.

The researcher also wished to establish the status of the various preparatory activities or measures that the QASOs put in place to increase the propensity of having effective instructional supervision in schools. This is summarized by Table 1.2

Table 1.2:- QASOs Preparation Activities before Conducting Instructional Supervision in Schools

\begin{tabular}{|c|c|c|c|c|}
\hline \multirow[t]{2}{*}{ Statement } & \multicolumn{2}{|c|}{ Agree } & \multicolumn{2}{|c|}{ Disagree } \\
\hline & $\mathbf{n}$ & $\%$ & $\mathbf{n}$ & $\%$ \\
\hline Have schedules for visiting institutions & 8 & 47.1 & 9 & 52.9 \\
\hline Lead assessor allocates duty to QASOs & 9 & 52.9 & 8 & 47.1 \\
\hline
\end{tabular}

Table 1.2 shows that while $9(52.9 \%)$ of QASOs indicated that there were no written schedules for visiting schools in their county, another $8(47.1 \%)$ indicated that there were such schedules. This divided opinion indicates that there is uncertainty amongst QASOs on the existence of written schedules for regularly visiting schools to specifically conduct instructional supervision as provided for by the Handbook for Supervision of Education Institutions (2000).

These findings tend to agree with the work of Kamindo (2008) who found that QASOs did not put a lot of weight in formulating their own schedules of work because their work depended on the instructions they received from the DEOs which was unpredictable. Absence of work schedules may imply that there is no much preparations that are carried out when QASOs decide to visit a school for instructional supervision, this may actually explain why there was almost consensus (Table 1.1) by school principals, heads of departments and QASOs that mostly schools are hardly notified of impending instructional supervision exercises.

Further, Table 1.2 above indicates that while most 9(52.9\%) of QASOs reported that Lead Assessor allocated duties to other QASOs for effective preparation of an instructional supervision exercise, $8(47.1 \%)$ of the QASOs were of the view that Lead Assessor hardly allocated duties before an impending instructional supervision exercise. This indicates that while most Lead Supervisors allocates duty to QASOs before instructional supervision exercises are held as a means for preparing for such exercises, an equally significant proportion of Lead Supervisors don't allocate duties at all.

The findings on the status preparedness of QASOs' before conducting instructional supervision in schools is contrary to Burrow (2012) who had found that in the Mombasa County Kenya, QASOs appeared unprepared when they visited an institution for instructional supervision because of poor preparation for such exercises and this resulted to poor service delivery. However, it should be noted that the Task Force on Alignment of the Constitution with Education had established; "Quality Assurance Services in Educational Institutions is manifested with uncoordinated decision-making at all levels" (Republic of Kenya, 2011). This apparently, indicates that QASOs were not doing very sufficient preparations before visiting a school for instructional supervision. 
Allocation of duties to QASOs by Lead QASO Assessor is a prerequisite of effective preparations for effective instructional supervision of schools (Ministry of Education, 2000). When the allocation is totally not done or it is done too late, then the implications are seen via ineffective instructional supervision exercises in schools.

\section{Conducting Actual Instructional Supervision:-}

This study sought to find out the main approach used by QASOs to engage the school principals and HoDs while conducting actual instructional supervision. The responses are presented in Figure 1.1

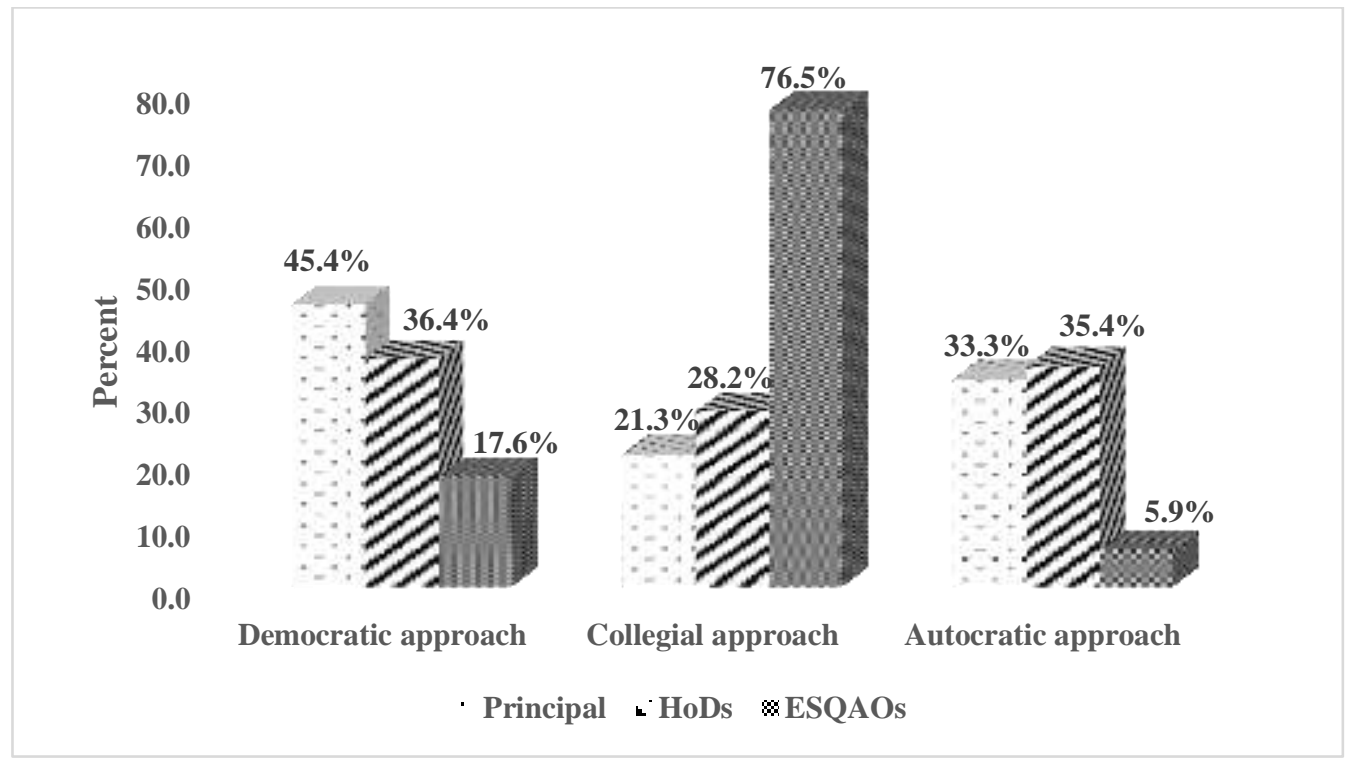

Figure 1.1:- Approaches used by QASOs when Handling Principals and HoDs

Figure 1.1 indicates that majority, 13(76.5\%) of QASOs reported that they used collegial approach when handling teachers. In other words, QASOs believe that they treat Principals and HoDs as colleagues while conducting instructional supervision. In this respect QASOs consider themselves as engaging and consultative in the whole process of instructional supervision. This is consistent with the study by Lews, (2002) who found that most educational instructional supervisors considered themselves as exercising collegiality in course of their instructional supervision.

However, Figure 1.1 indicates that; according to most 49(45.4\%) of the school principals and 109(36.4\%) of heads of departments the democratic approach was mostly used by QASOs when handling teachers and autocratic approach came closely second as reported by $36(33.3 \%)$ of the school principals and $103(35.4 \%)$ of the heads of department. This implies that generally most principals and heads of departments consider QASOs as exercising democratic tendencies while conducting instructional supervision. This in essence means that, in terms of what need to be done in respect to improvement of instructional competencies of teachers, the majority has their way and minority have their say. This type of approach of instructional supervision is inferior to collegial approach because it does not engage stakeholders (QASOs, Principals and heads of departments) in discussion in order to reach consensus when making (instructional) decisions (Tony, 2007) and therefore there is no complete ownership of decisions or actions being implemented.

The findings of this study also tends to be in agreement with Okendu, (2012) who found that in contemporary Nigeria, instructional supervision through democratic interactions between the Teacher and the Supervisor was found to be the most dominant approach of enhancing the professional growth and improving the techniques of teachers. However, these findings are contrary to Kamindo (2008) and Moswela (2010) who found that teachers seemed to view QASOs as being autocratic and that the environment in which instructional supervision took place in schools was rather autocratic with manifestations of silent hostility and intimidation to teachers.

As captured by one of the County QASO during the interview, thus;

"... after $i$ assess a teacher, most of them ask me to assess them in the next lesson...". 
This may indicate that an experience of an interaction with the QASOs could be what is missing for teachers who hold the view that QASOs are autocratic. Further maybe lack of complete involvement of teachers at all stages of instructional supervision could also explain why few principals and head teachers have the perception that QASOs don't use collegial approach during instructional supervision. To move towards collegiality, the QASOs need to be more conscious and involve the input of teachers during the stages of: preparation for conducting instructional supervision; initial meeting; pre-observational, observational and post observational conferences; and final plenary meeting in the school. As highlighted in the literature review, when teachers' belief that QASOs are collegial they tend to be positive towards instructional supervision, become open-minded and trusting (Sergiovanni \& Starratt, 2002) all which contributes to successful instructional supervision sessions.

This study also wished to establish from the principals and heads of departments which activities the QASOs preferred to concentrate on more between evaluative and advisory services, they responded as reported in Table 1.3

Table 1.3:- QASOs, Principals and HoDs Preferences on what QASOs should concentrate on

\begin{tabular}{|l|c|c|c|c|c|c|}
\hline \multirow{2}{*}{ Services } & \multicolumn{2}{|c|}{ Principals } & \multicolumn{2}{c|}{ HODS } & \multicolumn{2}{c|}{ QASOs } \\
\cline { 2 - 7 } & $\mathbf{n}$ & $\mathbf{\%}$ & $\mathbf{n}$ & $\mathbf{\%}$ & $\mathbf{n}$ & 29.4 \\
\hline Evaluative & 13 & 12 & 31 & 10.7 & 5 & 47.1 \\
\hline Advisory & 36 & 33.3 & 128 & 44.3 & 8 & 23.5 \\
\hline Both & 59 & 54.6 & 130 & 45.0 & 3 & $\mathbf{1 0 0}$ \\
\hline Total & $\mathbf{1 0 8}$ & $\mathbf{1 0 0}$ & $\mathbf{2 8 9}$ & $\mathbf{1 0 0 . 0}$ & $\mathbf{1 6}$ & \\
\hline
\end{tabular}

Table 1.3 indicates that, slightly above half 59(54.6\%) of school principals and 130(45.0\%) of Heads of departments reported that they would prefer QASOs to concentrate on both advisory and evaluative service when they visit schools. A good percentage 36(33.3\%) of school principals and 128(44.3\%) of the Heads of departments said that they would prefer them to concentrate on advisory. However, majority 8(47.1\%) of QASOs reported that they would prefer to concentrate on advisory roles. This shows that as much as majority of principals and HoDs were in consensus that QASOs should concentrate on both evaluate and advisory roles, all the respondents (principals, HoDs and QASOs) were of the opinion that QASOs should lay more emphases on advisory roles when they visit schools.

As captured in the literature review, QASOs have been mandated to carry out evaluative and advisory roles in furtherance to quality education provision in schools (Government of Kenya, 2001a): while the evaluative roles has to do with identification of instructional deficiencies of teachers like poor classroom control and lack of stimulus variation while teaching; the advisory roles has to do with addressing presumed or indentified teachers' instructional deficiencies like how to take care of learners' individual differences while teaching.

The sentiments of the majority of principals and HoDs on the preferred areas that QASOs should concentrate on agrees with Glickman et al., (2007) that the role of the supervisor when dealing with teachers would require him to first identify the needs of the teacher (evaluation) so as to effectively assist the individual teacher towards accelerated growth and development (advisory) using the developmental model of instructional supervision. However, the findings of this study in regards to QASOs preferring to concentrate on advisory roles are contrary to the findings of Kamindo (2008) who had found that QASOs rated evaluative roles functions higher than advisory functions. As advocated by Okumbe, (1998), instructional supervision should be based on: "what you see"observation (evaluative); "hear"- discussion (advisory); and "read"-documentation" (evaluation) which should be analyzed to form the bases of designing strategies of improving the teacher(advisory), an instructional supervision approach he called clinical supervision. One would only hope that QASOs are able to strike a balance between evaluation and advisory activities (Glickman et al., 2007).

The researcher sought to find, not only the arrival time for the QASOs but also how they conducted actual instructional supervision in the schools at various stages as judged by the Principals and HoDs. Table 1.4 presents these sentiments.

Table 1.4:- Principals and HoDs Responses on How QASOs Conduct Instructional Supervision

\begin{tabular}{|c|c|c|c|c|c|c|c|c|c|c|c|c|}
\hline \multirow[t]{3}{*}{ Variable } & \multicolumn{6}{|c|}{ School Principals } & \multicolumn{6}{|c|}{ Heads of Departments } \\
\hline & \multicolumn{2}{|c|}{ Yes } & \multicolumn{2}{|c|}{ No } & \multicolumn{2}{|c|}{ Not Sure } & \multicolumn{2}{|c|}{ Yes } & \multicolumn{2}{|c|}{ No } & \multicolumn{2}{|c|}{ Not Sure } \\
\hline & $\mathbf{n}$ & $\%$ & $\mathbf{n}$ & $\%$ & $\mathbf{n}$ & $\%$ & n & $\%$ & $\mathbf{n}$ & $\%$ & $\mathbf{n}$ & $\%$ \\
\hline
\end{tabular}




\begin{tabular}{|l|l|l|l|l|l|l|l|l|l|l|l|l|}
\hline $\begin{array}{l}\text { QASOs arrives school before } \\
\text { 8.30AM. }\end{array}$ & 57 & 52.8 & 51 & 47.2 & - & - & 101 & 34.8 & 189 & 65.2 & - & - \\
\hline Initial meeting are conducted & 57 & 52.8 & 36 & 33.3 & 15 & 13.9 & 140 & 48.6 & 78 & 27.1 & 70 & 24.3 \\
\hline $\begin{array}{l}\text { Pre-observation conferences are } \\
\text { conducted. }\end{array}$ & 26 & 24.1 & 57 & 52.8 & 25 & 23.1 & 84 & 28.8 & 154 & 52.7 & 54 & 18.5 \\
\hline $\begin{array}{l}\text { Observation conferences are } \\
\text { conducted. }\end{array}$ & 79 & 71.8 & 11 & 10.0 & 20 & 18.2 & 200 & 69.2 & 28 & 9.7 & 61 & 21.1 \\
\hline $\begin{array}{l}\text { Post observation conference } \\
\text { addresses areas of } \\
\text { improvement. }\end{array}$ & 64 & 58.7 & 17 & 15.6 & 28 & 25.7 & 180 & 62.5 & 51 & 17.7 & 57 & 19.8 \\
\hline $\begin{array}{l}\text { Final meetings are healthy and } \\
\text { areas of improvement are } \\
\text { discussed. }\end{array}$ & 52 & 47.7 & 32 & 29.4 & 25 & 22.9 & 188 & 65.3 & 44 & 15.3 & 56 & 19.4 \\
\hline
\end{tabular}

From Table 1.4, numerous observations can be made; first, while the majority, 57(52.8\%) of the school principals are of the opinion that QASOs arrival at the schools before 8.30am, majority 189(65.8\%) of the heads of departments reported that QASOs hardly arrived at the schools before 8.30am. Maybe the difference in opinion between principals and HoDs can be explained by the fact that, when QASOs arrive in the school they first report to the office of the Principal after which HoDs and teachers are informed of their presence. To this extent, it can be said that QASOs are able to arrive at the schools for instructional supervision at 8.30am which ideally gives them ample time to conduct through instructional supervision. As noted in the literature review, the QASOs are supposed to arrive early (before 8.30am) at the school they are scheduled to conduct instructional supervision so as to maximize on what they see and hear (Republic of Kenya, 2000).

When QASOs arrive early in schools, they are likely to maximize on what they "see"-observation; "hear"discussion; and "read"-documentation" (evaluation) which eventually makes the instructional supervision exercise successful.

Secondly, table 1.4 indicates that, majority $57(52.8 .5 \%)$ and $52(47.7 \%)$ of principals, and majority $140(48.6 \%)$ and $188(65.3 \%)$ of HoDs are in agreement that that: QASOs explains clearly issues to be assessed during the initial meeting, and that during the final meeting between QASOs and teachers there are healthy discussions on the findings of instructional supervision highlighting areas that need improvement respectively. As captured in the literature review during the initial meeting, QASOs clearly explains their instructional supervision mission, objectives and goals, while during the final plenary meeting the QASOs provide feedback of the conducted instructional supervision exercise highlighting areas of improvement. The success of these two meeting can therefore be an indicator of effective instructional supervision by the QASOs.

The findings of this study on how initial and final plenary meeting are conducted is in agreement with the works of Early (1998) and Chapman (2001a) who had found that teachers are always eager to be engaged in discussions and meetings on their instructional supervision before and after being supervised. Ideally, the involvement of teachers during the initial meeting before instructional supervision commences in a given school is generally likely to create a conducive environment for instructional supervision because they are informed of what to expect in the whole process. Ultimately, when the final meeting between the QASOs and teachers is healthy, this would imply that feedback offered at the school level is well discussed and way forward on instructional improvement is agreed.

Thirdly, Table 1.4 indicates that most 57(52.8\%) of principals and 154 (52.7) of HoDs reported that during preobservational conference teachers are not engaged in a discussion to establish how the actual classroom assessment will be conducted. This means that most of the teachers that are observed in class teaching during instructional supervision are hardly informed on the major variables (interaction between the teacher and pupils, involvement of all pupils, teaching from known to unknown, use of instructional materials, masterly of subject etc) that the QASOs focus on while observing the way they conduct their classes. While teachers are not briefly informed in advance of QASOs observational expectations in an ideal class, this may create uncertainty and they might not display their real self 
The finding of this study on pre-observational conference confirms Romano (2014) assertion that one of the most frequent complaints from teachers in respect to the process of the pre-observation is that it is never held. When the QASOs fail to conduct the pre-observational conference, they deny themselves and the teacher(s) to be supervised an opportunity to create a personalized rapport based on the nitty-gritty of how the actual class instructional supervision will be conducted which significantly can reduce any tension which could be there between the QASO and the teacher, consequently making the teacher behave normally when be supervised and ultimately bringing-out his/her strong and weak points. The net effect of this is that, the instructional supervisor is likely to note the right observations during observational conference and ultimately give the right feedback in terms of instructional improvement during the post-observational conference.

Lastly, Table 1.4 shows that: vast majority, 200(69.2\%) and 180(62.5\%) of HoDs; and 79(71.8\%) and 64(58.7\%) of the school principals were in agreement that: QASO conduct observational conference professionally without humiliating the teachers; and post observational conference is also professionally done, appropriately addressing areas of improvement respectively. This indicates that majority of principals and HoDs are in agreement that QASOs are humane, understand the various instructional weakness that teachers might have and are professional (respect teachers, maintain confidentiality etc) while conducting observational and post observational conferences.

These findings are contrary to the works of Romano (2014), Kisirkoi (2014) and Ogandoh (2015) who found that most QASOs gave ambiguous statements and comments during the post-observational conference and that many teachers did not professionally benefit from observations made by supervisors in the classroom observation. These imply that there is variance in the instructional supervision practices of conducting observational and post observational conferences. The variance maybe due to differential level of knowledge among the QASOs on how observational and post observational conferences should be conducted

When observational and post-observational conferences are professionally done, it implies that to a greater extent right observations are noted when the teacher are being observed while facilitating teaching and based on these observations right feedback on areas to improve are highlighted in the post-observational conference. This culminates in instructional improvement to the concerned teacher. The researcher sought to find out from principals and HoDs which areas the QASOs concentrated on when they visited schools. This is reported in Table 1.5

Table 1.5:- Principals' and HoDs' Ranking of the Areas That QASOs Concentrate on During for Instructional Supervision.

\begin{tabular}{|c|c|c|c|c|c|c|c|c|c|c|c|c|}
\hline \multirow[t]{3}{*}{ Variable } & \multicolumn{6}{|c|}{ School Principals } & \multicolumn{6}{|c|}{ HoDs } \\
\hline & \multicolumn{2}{|c|}{1} & \multicolumn{2}{|c|}{2} & \multicolumn{2}{|c|}{3} & \multicolumn{2}{|c|}{1} & \multicolumn{2}{|c|}{2} & \multicolumn{2}{|r|}{3} \\
\hline & $\mathbf{n}$ & $\%$ & $\mathbf{n}$ & $\%$ & $\mathbf{n}$ & $\%$ & $\mathbf{n}$ & $\%$ & $\mathbf{n}$ & $\%$ & $\mathbf{n}$ & $\%$ \\
\hline $\begin{array}{l}\text { Checking; schemes of work, lesson } \\
\text { plans, registers \& lesson notes }\end{array}$ & 81 & 75.0 & 14 & 13.0 & 13 & 12.0 & 159 & 60.7 & 49 & $\begin{array}{l}18 . \\
7\end{array}$ & $\begin{array}{l}5 \\
4\end{array}$ & $\begin{array}{l}20 . \\
6\end{array}$ \\
\hline Observing teachers in classrooms & 16 & 15.2 & 39 & 35.5 & 50 & 47.6 & 44 & 16.7 & $\begin{array}{l}12 \\
3\end{array}$ & $\begin{array}{l}46 . \\
8\end{array}$ & $\begin{array}{l}9 \\
6\end{array}$ & $\begin{array}{l}36 . \\
5\end{array}$ \\
\hline
\end{tabular}

As shown by Table 1.5, three quarter $81(75.0 \%)$ of the school principals and $159(60.7 \%)$ of the heads of departments ranked checking records like schemes of work, lesson, plans, registers, lesson notes etc. as the most important area where QASOs mostly concentrate on when conducting instructional supervision. This implies that according to principals and HoDs, when QASOs visit schools for instructional supervision, they mostly concentrate on checking records like schemes of work, lesson, plans, registers and lesson notes. Therefore might indicate that most of the findings and recommendations on instructional supervision may be dominated by issues relating to the status of the teachers professional records. Maybe the reasons as to why QASOs concentrate on checking teachers' professional records might be motivated by the fact that it's the fastest indicator of what has been transpiring in classroom as far as teaching in concerned.

This finding in regard to checking teachers' professional records concurs with Okumbe (1998) who observed that there is excess paper work and rigid rules in the process of supervision making the supervision process to be centered on whether teachers have un-updated or updated records. However, as Daresh and Playko, (1992), noted "professional supervision" done in areas of checking on lesson plans, schemes of work, registers and other administrative documents had positive impact in academic performance of pupils. Indeed, Usman (2015) affirmed that regular instructional supervision using robust supervision strategies like checking of students' notebooks, 
checking teachers' lesson plan/notes and inspection of teachers' record keeping have significant correlation with teachers' performance and academic achievement of students in secondary schools. In this respect, (Ministry of Education, 2000) advices the QASOs to maximize on what they "see, hear and read" during instructional supervision exercise. One would therefore caution that overconcentration in checking teachers' professional records amounts to "reading" to much at the expense of "seeing and hearing".

Indeed, Wanzare (2012) observed that overconcentration in checking teachers' professional records amounted to establishing bureaucratic regulations and procedures which does not promote effective instructional supervision practices.

Observing teachers in classrooms was ranked third by most 50(47.6\%) of school principals and second by most $123(46.8 \%)$ of the heads of departments. This implies that school principals and heads of departments are in agreement that QASOs don't concentrate on observing teachers in classrooms as they do when it comes to checking teachers' professional records. Maybe the reason why QASOs don't concentrate a lot on observing teachers in classroom is because it's tedious and time consuming exercise in the many number of teachers in a given school. However, it should be noted that observing teachers in classroom provides primary raw data on the status of an individual teacher' instructional abilities as compared to checking teachers' professional records. Indeed, in advocating for a balance between checking of teachers' professional records, observing teachers in classroom, Mclaughlin \& Zarrow (2001) established that most useful instructional supervision occur when there are meaningful interactions between teachers and supervisors; hence observing teachers in classroom teaching and holding discussions with them in their departments should be balanced with checking of professional records.

The success of instructional supervision exercise depends heavily on the cooperation between the principals, HoDs and QASOs, in this connection therefore the study sought to establish whether the key participants felt that there existed cooperation when instructional supervision was being conducted. This is represented by the Figure 1.2

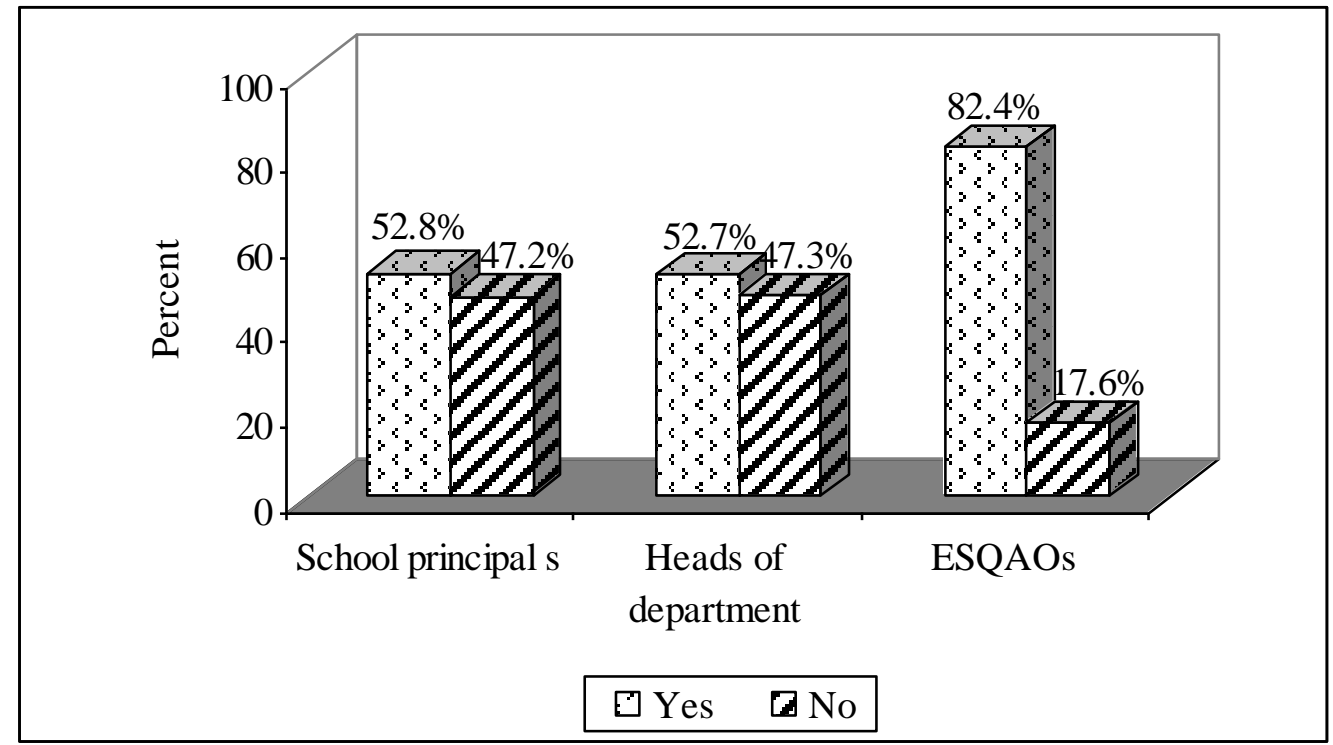

Figure 1.2:- Principals', Heads of Departments and QASOs' Responses on Status of Cooperation between QASOs and Teachers

Figure 1.2 indicates that majority 14(82.4\%), 57(52.8\%) and 154(52.7\%) of QASOs, school principals and HoDs respectively are in agreement that there is cooperation between QASOs and teachers during instructional supervision exercise in public schools. This means that the instructions, directives, requests etc given by QASOs to teachers during instructional supervision are adhered to and that QASOs pay attention to any requests given by teachers in course of conducting instructional supervision. Such an environment enables the process of instructional supervision to be conducted smoothly in schools.

This study finding is in agreement with Karugo (2015) who found that generally there was cooperation between QASOs and teachers in terms of their interaction and relations during the conduct of the instructional supervision 
visits. Such cooperation imply that teachers not only avail themselves as required but they also avail needed documents for the instructional supervision, all which makes the supervision exercises successful because the status quo of the instructional practices in a school can be established and hopefully professionally corrective measures are identified and implemented, all which can go a long way in improving the quality of education offered in schools.

\section{Preliminary Instructional Supervision Reports and Feedback:-}

A key component of effective instructional supervision is the collection of requisite data to be used in informing the type of feedback to be given at the end of instructional supervision exercise. This study sought to establish whether; QASOs are able to pick out key findings of instructional supervision, if the findings are well argued with supportive evidence and finally if QASOs spare enough time to give feedback to the teachers at the school level. This is presented in Table 1.5

Table 1.5:-QASOs Competences in Compiling and Presenting Preliminary Instructional Supervision Reports at the school Level

\begin{tabular}{|c|c|c|c|c|c|c|c|c|c|c|c|c|}
\hline \multirow[t]{3}{*}{ Variable } & \multicolumn{6}{|c|}{ School Principals } & \multicolumn{6}{|c|}{ Heads of Departments } \\
\hline & \multicolumn{2}{|c|}{ Yes } & \multicolumn{2}{|c|}{ No } & \multicolumn{2}{|c|}{ Not Sure } & \multicolumn{2}{|c|}{ Yes } & \multicolumn{2}{|c|}{ No } & \multicolumn{2}{|c|}{ Not Sure } \\
\hline & $\mathbf{n}$ & $\%$ & $\mathbf{n}$ & $\%$ & $\mathbf{n}$ & $\%$ & $\mathbf{n}$ & $\%$ & $\mathbf{n}$ & $\%$ & $\mathbf{n}$ & $\%$ \\
\hline $\begin{array}{l}\text { QASOs findings highlight } \\
\text { areas for improvement }\end{array}$ & 52 & 47.7 & 32 & 29.1 & 25 & 22.7 & 188 & 65.3 & 44 & 15.3 & 56 & 19.4 \\
\hline $\begin{array}{l}\text { Sufficiency time for } \\
\text { delivering feedback }\end{array}$ & 39 & 35.5 & 48 & 43.6 & 23 & 20.9 & 92 & 31.8 & 150 & 51.9 & 47 & 16.3 \\
\hline $\begin{array}{l}\text { QASOs reports are argued } \\
\text { with supportive evidences }\end{array}$ & 37 & 33.6 & 34 & 30.9 & 39 & 35.5 & 126 & 43.9 & 77 & 26.8 & 84 & 29.3 \\
\hline
\end{tabular}

Table 1.5 indicates that the majority, 52(47.7\%) of school principals and $188(65.3 \%)$ heads of departments said that during the final meeting between the QASOs and the teachers, the QASOs present their main findings of instructional supervision highlighting areas that needed improvement. However, majority 48(43.6\%) of the school principals and $150(51.9 \%)$ of the heads of the departments reported that there was usually no sufficient time for delivering feedback and engaging teachers at the end of the instructional supervision. This implies that there is a culture of QASOs to present their final findings of an instructional supervision in schools during the final plenary session as provided by the ESQAC guidelines (Government of Kenya, 2001a). However, during these final plenary sessions there is hardly enough time for the teachers to interrogate the findings or recommendations presented by the QASOs. May a lot of time is allocated to other instructional supervision activities at the expense of the final plenary meeting or the QASOs dominate the final meeting; both of which should not be the case.

These findings are consistent with Ogandoh (2015) who found that although most teachers found Educational Supervisors highlighting areas that needed to be improved after supervising teachers, majority of the school principals found QASOs allocating insufficient time for interacting with teachers at the end of an instructional supervision exercise. This implies that the QASOs dominate the final plenary session and teachers' sentiments are hardly given an opportunity to be heard, consequently there is no ownership on the proposed way forward on how to generally improve instruction in the school given the findings of an instructional supervision exercise. Lack of ownership on proposed way forward of improving instruction in a school can be a recipe for failure of implementation.

Also captured in the Table 1.5, although majority 126(43.9\%) of heads of departments said that the report presented by QASOs at final meeting were always well argued where supportive evidences were collated, most 39(35.5\%) school principals were not sure on the same. Studies by Juvenale, 2017; Kayaoglu, 2012; and Kutsyuruba, 2003 indicates that instructional supervision is likely to reach its expected goal when the relations between the supervisors and teachers are collegial and teachers have an opportunity to discuss aspects of their teaching with supervisors during the plenary meeting in a secure and nurturing climate. Ministry of Education (2000) provides that comprehensive and teacher centred feedback sessions should occur during the final meeting between the QASO panel, the principal and the staff. During these meetings, major highlights or findings of the instructional supervision are supposed to be discussed and 'the discussion should be professional and friendly'. To this effect, the contradicting sentiments expressed by principals and HoDs tend to imply that the competences of QASOs in preparing agenda and facilitating for the final plenary meeting may be described as satisfactory. 


\section{Conclusions and Recommendations:- \\ Conclusions:-}

The study found that most of school principals (schools) didn't receive letters from QASOs notifying them in advance of their intentions to visit them for instructional supervision. Majority of QASOs were in agreement with majority of Principals and of HoDs that there was optimal cooperation between QASOs and the teachers during the whole exercise of instructional supervision. In respect to utilization of previous instructional supervision to inform the preparation for instruction supervision of schools by the QASOs, the study established that most of school principals and of heads of departments felt that previous supervision reports were not and were only used to a little extent respectively to inform the preparation for instruction supervision of schools by the QASOs.

The study established that while majority of QASOs felt that they used collegial approach when handling Principals and HoDs during instructional supervision, majority of principals and of heads of departments reported that QASOs use democratic approach. On whether, QASOs should concentrate on advisory or evaluative services, the study revealed that, most of school principals and Heads of departments preferred QASOs to concentrate on both advisory and evaluative service when they visit schools, while majority of QASOs reported that they would prefer them to concentrate on advisory. Further, the study established that majority of principals and HoDs were in agreement that: QASOs are organized and Lead Assessor clearly explains issues to be assessed during the initial meeting; QASOs spend most of the time checking schemes of work, lesson plan, record of work, pupils' progress records and departmental records. Indeed, according to this study, majority of the school principals and heads of departments ranked checking records like schemes of work, lesson, plans, registers, lesson notes etc. as the most important area that QASOs mostly concentrate on during instructional supervision.

This study also established that most of the HoDs were in agreement with most of the principals that: QASO conduct observational conference professionally without humiliating the teachers; conduct post observational conference in a professional manner, appropriately addressing areas of improvement; and finally during meeting between teachers and QASOs, there is always a healthy discussion where the main findings of instructional supervision are highlighted. However, the study found that majority of the principals were in agreement with majority of the HoDs that; teachers who are supposed to be observed in classroom teaching (observational conference) are hardly engaged in pre-observational conference to establish how the classroom assessment will be conducted.

In regards to the final meeting between QASOs and teachers, the study established that majority of school principals and heads of departments felt that during the final plenary meeting between the QASOs and the teachers, there was always a healthy discussion based on the main findings of instructional supervision highlighting areas that needed improvement. However, the study found that majority of the school principals and heads of the departments were of the opinion that there was usually no sufficient time for delivering feedback and engaging teachers in such meetings in planning future strategies.

\section{Recommendations:-}

In regard to preparation for conducting instructional supervision, this study recommends that; it be made mandatory by the MoEST and circulars be sent to schools to the effect that any school to be visited by QASOs for instructional supervision to be notified through writing at least one month in advance and teachers to be observed in classroom teaching to have a right not to oblige until they are taken through pre-observation conference.

On the activities that the QASOs concentrates on during instructional supervision, this study recommends that the QASOs should predetermine and equitably share the time available for instructional supervision exercise between; checking professional records, observing teachers in classes, and giving feedback.

In regard to delivery of feedback at the school level during the plenary session, this study recommends that any instructional supervision in schools should done in two days so that one day is for through assessment and the second day is for sharing. This should also be communicated by MoEST via circulars to all schools and copies put in staff rooms. 


\section{References:-}

1. Bolin, F.S., \& Panarities, P. (1992). Searching for a common purpose: A perspective on the history of supervision in transition in C.D. Glickman (Ed), Supervision in transition the 1992 yearbook (pp 30-43). USA: Association of Supervision and Curriculum Development.

2. Cohen, L., Manion, L. and Morrison, K. (2004). Research methods in education. (5 ${ }^{\text {th }}$ d.). London: Routledge Falmer.

3. Daresh, J.C, Playko, M.A. (2002) The Professional Development of School service, induction, and in-service Application, in Allyn and Bacon, MA. Pp 234-432

4. Dolton, P. and W. van der Klaauw (1999) 'The turnover of teachers: A competing risks explanation. 'Review of Economics and Statistics, 81(3): 543-50.

5. Early, P. (Ed). (1998). School Improvement after Inspection? School and LEA Responses. London; Paul Chapman Publishing ltd.

6. European Commission/EACEA/Eurydice, 2015. Assuring Quality in Education: Policies and Approaches to School Evaluation in Europe. Eurydice Report. Luxembourg: Publications Office of the European Union

7. Fraser, K. (1980). Supervisory behaviour and teacher satisfaction. Journal of Education Administration, 18(2), 224-227.

8. Goldhammer, R.H., Anderson, R.H., \& Krajewski, R.J. (1980). Clinical supervision: special ethods for the supervision of teachers. New York: Holt, Rinehart and Winston Inc

9. Hasan, B. (2012). The Issue of Education Supervision in Turkey in the Views of Teachers, Administrators, Supervisors and Lectures. Educational Sciences; Theory \& Practice, 12(1). 149-156

10. Harris, B., \& Ovando, M. (1992). Collaborative supervision and development evaluation of teaching. Journal of Teachers Association of New York State, 23, 12-18.

11. Juvenale, P.A. (2017) Human Relations in Instructional Supervision: EFL Trainess' Appraisal of a TEFL Practicum. English Linguistics Research, Vol. 6, No.1;2017. Retrieved from URL: http://dx.doi.org.10.5430/elr.v6nlp38

12. Kamindo, C. (2008). Instructional supervision in an era of change: policy and practice in primary education in Kenya, Unpublished PhD Thesis: Durham University, United Kingdom.

13. Kayaoglu,M.N. (2012). Dictating or facilitating: The supervisory process of language teachers. Australian Journal of Teacher Education, 37(10), 103-117. https://doi.org/10.1422/ajte.2012v37n10.4

14. Kimuya, E. (2004). Barriers to effective supervision of instruction in public secondary schools administration of Bahati division of Nakuru Sub-county, Unpublished Med. Project: Kenyatta University.

15. Kilemi, M. (2010, October 27). Medicine for the failing quality of education in public schools. Standard Newspaper, pp. 27, 29

16. Kutsyuruba, B. (2003). Instructional supervision: Perceptions of Canadian and Ukrainian beginning highschool eachers (Master's thesis). Saskatoon: University of Saskatchewan. [online] http://library2.usask.ca/theses

17. McLaughlin, M. \& Zarrow, J. (2001) “Teachers engages in evidence-based reforms: Trajectories of teachers' inquiry, analysis, and action" New York. Teachers' College Press

18. Moswela, B. (2010). Instructional Supervision in Botswana Secondary Schools: An Investigation. Educational Management Administration \& Leadership, 38(1), 71-87.

19. Mwaura, G. (2014) The Role Of Quality Assurance And Standard Officers In Promoting Education In Private Secondary Schools In Limuru District, Kiambu County. Unpublished M.Ed. Thesis. Kenyatta University.

20. Naci, M.K., (2012). Dictating or Facilitating: The Supervisory Process for Language Teachers. Australian Journal of Teacher Education, (37)10. October 2012, 103-117

21. Njiru, P. (2014) Efficiency in resource utilization in primary schools in Kenya: A case of Gatundu North District, Kiambu County, Kenya. Unpublished M.Ed. Thesis. Kenyatta University.

22. Ogandoh, G.L.,(2015). Teachers' Perception on the Role of Quality Assurance and Standards Officers in Public Secondary Schools in Busia Sub-County. Unpublished M.Ed. Thesis. Kenyatta University

23. Okumbe, J.A. (1998). Educational management, theory and practice. Nairobi: Nairobi University Press.

24. Olembo, J. A., Wanga, P.E., \& Karagu, N.M. (1992). Management in education. Nairobi: Education Research and Publications (ERAP)

25. Richard, K., \& William, W. (2001). The conference category systems help supervisors analyze their conferences with teachers. Kent State University, Ohio

26. Romano, Vincent A., Jr. (2014). Secondary teachers' and their supervisors' perceptions of current and desired observation practices. Global Education Review, 1 (3). 135-146

27. Semiha, S., Fatma, C. \& Nalan, Z. (2011). Education Supervisors' Views Regarding Efficiency of System and 
In-service Training Courses. Educational Sciences; Theory \& Practice, 11(3). 1196-1201

28. Sergiovanni, T. \& Starratt, R. (2007). Supervision: A redefinition. (8th ed.). New York: McGraw-Hil

29. Tesfaw, T. \& Hofman, R. (2012). Instructional Supervision and Its Relationship with Professional Development: Perception of Private and Government Secondary Schools in Addis Ababa. Unpublished Med Thesis, University of Addis Ababa.

30. Thembinkosi, T., (2013) Teachers' Perceptions towards Classroom Instructional Supervision: A Case Study of Nkayi District in Zimbabwe. International J. Soc. Sci. \& Education 2013 Vol.4 Issue 1, ISSN: 2223-4934 E and 2227 393X Print

31. Tyagi, R. (2011) Academic Supervision in Secondary Schools: School-Base Approach for Quality Management. National University of Educational Planning and Administration 17-B, Sri Aurobindo Marg, New Delhi-110016 (INDIA)

32. Usman,Y.D.,(2015).The Impact of Instructional Supervision on Academic Performance of Secondary School Students in Nasarawa State, Nigeria. Federal Road Safety Commission (FRSC), RS4.35 Nassarawa Eggon Unit Command, Nasarawa State, Nigeria. Journal of Education and Practice www.iiste.org.ISSN 2222-1735 (Paper) ISSN 2222-288X (Online)Vol.6, No.10, 2015

33. Wango, G.M. (2002). The legal framework of Kenya education system: Nairobi: Kenya Education Staff Institute (KESI)

34. Wanzare, Z. (2012). Instructional Supervision in Public Secondary Schools in Kenya. Educational Management Administration \& Leadership, 40(2), 188-216.

35. Zepeda, S. J. (2007). Instructional supervision: Applying tools and concepts. [Online] www.eyeoneducation.com/. 
